DOI: 10.15587/2312-8372.2019.155847

\section{Gorin P., Tymkiv D., Bratakh M. Filipchuk 0.}

\title{
APPROVAL OF OPTIMAL PIPELINE'S CLEANING METHODS ACCORDING TO MULTIPHASE FLOW PATTERNS
}

Об’єктом досліджень є система збору і міжпромислового транспортування газу газових $і$ газоконденсатних родовищ.

Одним із найбільших проблемних місць є відсутність комплексного підходу $і$ обтрунтування вибору оптимальних методів очищення (звільнення від накопичених забруднень) внутрішньої порожнини газопроводів, що формують иі системи. Це призводить до неефективного використання обладнання для очистки трубопроводів $і$ значних експлуатачійних витрат без видимого економічного ефекту. На основі аналізу життєвих ииклів родовища встановлено, що для кожного із етапів розробки родовищ, притаманна різна структура газорідинних потоків.

В ході виконання роботи досліджено рельєфну характеристику трубопроводів системи збору і міжпромислового транспортування газу, що транспортують газорідинний потік із різним газовмістом. На основі аналізу критеріїв, що характеризують структуру потоку, представлено математичні моделі загальних перепадів тиску на висхідних і низхідних ділянках. Визначені перепади тиску формуються відповідно до різних структур руху газорідинних потоків під впливом гідравлічного опору кожної із досліджуваних ділянок.

Представлено очінку гідравлічного стану системи, що транспортує багатофазове середовище, яка базується на порівнянні фактичного виміряного перепаду тиску та його розрахункової величини. На основі експериментальних досліджень встановлено, що найбільш небезпечним чинником в експлуатації таких систем є можливість проходження залпових викидів рідини при зміні баричного режиму експлуатації.

3 метою підвищення надійності та ефективності експлуатацї газопроводів запропоновано алгоритм визначення структурної форми руху і фактичних досліджень гідравлічного стану системи збору та міжпромислового транспортування різних типів родовищ. А також розроблено послідовність вибору оптимального способу очищення порожнини трубопроводу.

Запропонований алгоритм вибору оптимальних способів відведення рідини з порожнини трубопроводу забезпечить можливість відкинути завідома неефективні методи, що в результаті зекономить час та кошти для Компаніі.

Ключові слова: газорідинний потік, міжпромисловий газопровід, структура потоку, очищення порожнини трубопроводу.

\section{Introduction}

The gas-producing complex contains in its composition a complex pipeline system, which performs two functions collection and inter-industrial gas transportation. The gas pipeline system receives and transports its own production gas, contains loops industrial pipelines that feed gas to gas preparation unit (GPU), booster compressor stations (BCS) or linear compressor stations (CS). The type of the technical characteristics, as well as the performance of the compressor equipment and pipelines depends on the capacity value of the system as a whole. Thus, the capacity of the gas collection and gas transmission system depends both on the operating modes of the ground infrastructure facilities and on each of the linear sections.

The throughput capacity of a gas pipeline system as a function of mode parameters is the main production indicator characterizing the efficiency of using gas pipelines for their intended purpose. The value of the capacity of the system is most affected by the technical characteristics of pipelines and their pressure conditions. If to consider a separate gas pipeline with a certain technical characteristic, then its pressure regime and, accordingly, its throughput capacity are closely related to the operating conditions. In particular, the presence of liquid condensation conditions, plugging, an increase in the hydraulic resistance of the sections, and, accordingly, the total pressure drop in the gas pipeline as a whole. Accordingly, excessive pressure drop affects either the level of the initial pressure, reducing gas production at the final stage of development in the gas mode, or the value of the final pressure, increasing the BCS energy consumption for gas transportation. Reducing the pressure drop occurs with a corresponding increase in throughput of gas pipelines, which is achieved by introducing methods of freeing them from liquids, such as cleaning with pistons, switching to self-cleaning mode, tapping drainage devices and drips of various designs.

Depending on the stage of field development, various flow structures form in the cavity of pipelines, respectively, forming various hydraulic supports [1]. So, the methods for clearing the cavity of gas pipelines from these contaminations will be different, and a separate algorithm must be created for their selection.

Accordingly, given the fact that the overwhelming majority of the fields in the oil and gas production sector of Ukraine are at the final stage of development, which is characterized by a high gas-producing factor, the question 
of minimizing pressure losses in the system for collecting and transporting hydrocarbons remains.

\section{The object of research and its technological audit}

The object of research is the system for the collection and inter-industrial transportation of gas from gas and gas condensate fields.

Today, Ukraine belongs to the countries with a developed oil and gas industry and oil and gas transportation industry. The first step in the development of the industry was made a century and a half ago, when the lighting of the streets of one of the cities of Ukraine - Lviv artificial, produced from coal by gas.

Considering the large branching of the system for the extraction and transportation of hydrocarbon products, as well as the remoteness of industrial facilities from each other, the length of the system for extracting and transporting oil and gas products is about 12 thousand $\mathrm{km}$.

At this stage of operation of the oil and gas sector of Ukraine, most of the fields are operated at the final stage of development, characterized by a significant decrease in reservoir pressure, low well rates, high content of reservoir water and hydrocarbon condensate in reservoir products.

Therefore, taking into account the existing technical condition of the system, as well as the age factor of oil and gas fields under operating conditions, the development and selection of optimal methods for cleaning pipelines for various structures of multiphase flows is a problematic issue.

\section{The aim and objectives of research}

The aim of research is determination of a wide range of similarity criteria, which describe the movement of multiphase flow in pipelines of the gas-collecting and productcollecting systems with a wide range of content of natural and associated gas in the mixture.

To achieve this aim it is necessary to perform the following objectives:

1. To investigate sections of pipelines on which structural flows follow each other in length and lead to a constant transition of one form to another.

2. To develop an algorithm for determining the structural form of gas-liquid flow, assess its type and uniformity, as well as determine the parameters of the hydraulic state.

3. To develop an algorithm for choosing the best ways to drain fluid from the cavity of the pipeline according to their principle of operation.

\section{Research of existing solutions of the problem}

Any gas pipeline oil and gas system can be considered as a transported gas-liquid flow with different gas content in the flow structure. That is why in world practice these structures are modeled in separate simulation programs, depending on how the flow is considered.

Schlumberger's PipeSim simulator is used for analytical studies, such as well modeling, optimization of mechanized production, modeling of pipelines and process equipment [2].

Weatherford's WellFlo software is a standalone application for designing, modeling, optimizing, and troubleshooting oil and gas wells operating in both the fountain and mechanized mode. This product allows the engineer to build models of wells and pipelines using a convenient user interface. Models constructed in this way accurately reflect the flow of any type of fluid from the reservoir, as well as the flow in tubing (tubing) and land lines [3].

Another of the software tools in which it is possible to create integrated models from the field to the preparation system is Petex of the Petroleum Experts company [4].

It is also like to mention the software simulator of the unsteady multiphase flow OLGA from Schlumberger. The dynamic multiphase simulator OLGA allows to calculate changes in flow parameters in wells and pipelines as a function of time, that is, to simulate stationary and transient flow regimes [5].

In national practice, for modeling flows, the provisions for calculating hydraulic parameters set forth in [6] are supplemented by methods of the Ukrainian Research Institute of Natural Gases (UkrNDIGas) [7]. These methods are based on the treatment of theories $[8,9]$ to determine the boundary between liquid accumulations in lower sections of the pipeline.

In fact, the use of these methods allows to determine the amount of contamination in the cavity of the pipeline, as, for example, proposed in scientific work [10]. Or to monitor the work of a number of pipelines, form the gas collection system of fields, as provided for by regulatory documents like [11].

To date, much attention is paid to the study of twophase flow. Models of gas and liquid movement in pipes have been developed, new methods for determining the amount of liquid in a gas pipeline cavity and methods for extracting liquid from a gas pipeline have been created, and devices for removing liquid have been modernized. One of such methods is the method of creating a pulsed mode of the working gas flow [12].

Therefore, solving the problem of analyzing the operating modes of pipelines in the oil and gas sector, identifying problem areas from the point of view of the deterioration of hydraulic efficiency, as well as justifying the feasibility of implementing measures to clean gas pipelines are promising issues.

When solving the problem of cleaning the pipeline, it is necessary to find out the causes of the ingress of fluid and the amount. This will provide an opportunity to monitor any changes in the process of operation and make a timely decision on the time and method of cleaning. It should also be noted that the amount of pollution in gas pipelines, calculated theoretically, differs from a certain experimental one. Therefore, this problem requires detailed study.

In addition, attention should be paid to the differences in the approach to cleaning the internal cavity of the field pipelines. In accordance with the requirements of regulatory documents, the decision on cleaning this type of pipelines is made solely on the basis of an internal pipe inspection [13], which is virtually impossible to do in Ukrainian specific conditions, which are described in detail in [14].

However, it should be noted that in any conditions, a multiphase medium will form in the pipeline cavity. This medium is considered to be relatively stationary under the operating conditions of mature fields, or it constantly changes its shape when it is localized in low places under the condition that the thermobaric mode of operation is changed [15]. Although, on the other hand, the problem of the behavior of multiphase media under conditions 
of changing temperature and pressure conditions of the pipeline is mainly highlighted for oil pipelines and collector threads collecting oil, considering the possibility of formation of both paraffin deposits [16] and tar [17, 18].

The processes of fallout and the formation of fluid accumulations in gas collection systems are more specific. Such pollutants are more mobile when the main pollutant is gas condensate, and more resistant to localization at the final stage of field development, when they will be formed exclusively from water fractions only with traces of condensate. In any cases, experts recommend a comprehensive survey of pipeline sections where fluid accumulation is possible [19].

In [20] it is presented that to prevent the accumulation of liquid contaminants in the cavity of the pipeline in the ascending sections of pipelines, measures were taken to replace the plumes of large diameters with smaller ones. Accordingly, these measures were carried out with the aim of ensuring the minimum necessary gas velocities to ensure the removal of fluid in the complex gas treatment units (CGTU).

Accordingly, it remains an open question how to choose the best method for removing the formed amount of pollution, because according to the stage of field development, the effectiveness of their implementation will be different. First of all, it is necessary to evaluate the structure of the flow, the homogeneity of the liquid formation in the pipeline cavity (define its structure as a mobile dispersed or plug or existing homogeneous mass, which is in a state of relative rest). And at the last stage, choose the most optimal method for draining the liquid from the cavity of the pipeline.

\section{Methods of research}

To develop an algorithm for determining the structure of a homogeneous flow and the flow of homogeneous flows, it is necessary to perform a series of successive steps:

- to draw up a profile of the pipeline route profile;

- to determine the equivalent ascending and descen-

ding sections of the route and carry out their hydraulic calculation.

The longitudinal plan-profile of the pipeline route is designed to determine the effect of the terrain on the formation of zones of increased hydraulic resistance to the movement of a liquid-gas stream (localization of water, paraffins, mechanical impurities) and zones of formation of gas caps. These processes increase the rate of pressure change in the pipeline under conditions of a constant flow of fluid in its cavity as a result of mechanical removal from the wellhead or separation equipment [21].

The development of technology now makes it possible to use simple, publicly available software products for the compilation of longitudinal plan-profiles of the route, such as Google Earth. These software systems provide only a binding to the terrain of the pipeline route with automatic profile construction.

The ascending segment of the equivalent route is considered to be such a segment between the crossing points of the real profile, along which, regardless of the number and slope of the intermediate sections, the mixture moves only upwards.

The length and the first equivalent ascending section are taken as the total length of the ascending sections of the real route between two crossing points (Fig. 1). Such an algorithm is completely based on the provisions of [6] and is described in detail in [21].

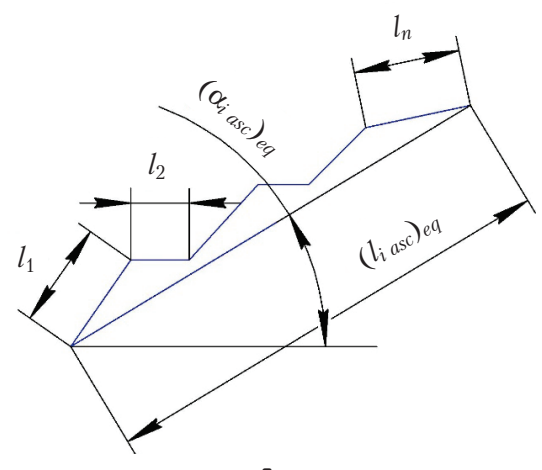

$a$

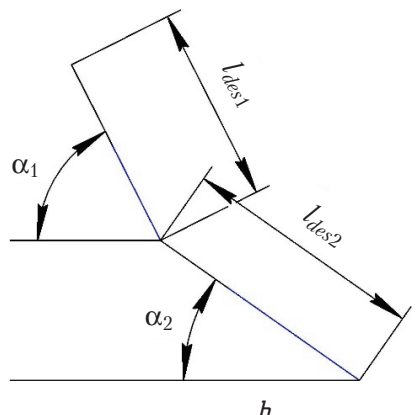

Fig. 1. Scheme for determining the length of the $i$-th section: $a$ - ascending; $b$ - descending

Determination of the equivalent ascending and descending part of the route:

$$
\left(l_{\text {iasc }}\right)_{e q}=\sum_{k=1}^{n} l_{\text {kasc }},
$$

where $l_{\text {kasc }}$ - the length of the $k$-th section, which is included in the ascending section between the crossing points, $\mathrm{m}$.

For the angle of inclination of the ascending equivalent area, the average angle of inclination is taken, which is determined by the condition:

$$
\left(\sin \alpha_{i a s c}\right)_{e q}=\frac{H_{s}-H_{e}}{\left(l_{\text {iasc }}\right)_{e q}},
$$

where $H_{s}-H_{e}-$ marks the starting and ending points of the ascending section, $\mathrm{m}$.

In fact, the use of such an algorithm significantly increases the time required for the project, since the number of ascending and descending sections, according to the length of the investigated gas pipeline, can reach hundreds or more. This ultimately leads to the need to process large amounts of data for weeks. The use of the above software systems reduces the time required for processing to several hours.

In the future, after determining the geometry of an elongated gas pipeline in space, an assessment of the structural flow of the work should be carried out, which involves the determination of criteria describing the flow structure in dimensionless quantities. 


\section{Research results}

6.1. Experimental studies. Conventionally, a multiphase mixture is at least two components: liquid and gas rise from the bottom of the well and move to the horizontal component of the gas production system. Depending on the type of a deposit, liquids may differ in density and viscosity, forming both emulsion formations and separate isolated structures during transportation. In addition, suspensions of the compound may appear in the gas-liquid stream as a result of mixing the liquid with solid impurities (clay deposits, sandstones, drilling mud residues, propping agent, etc.).

Conventionally, in the life cycle of a field, there are three main stages, as shown in Fig. 2:

1) early (high pressures, high speeds, leading to dispersion of one type of fluid in another);

2) stage of stabilization (intensification) of production, characterized by the formation of plug structures moving between parts of the system;

3) late, at which the drop in production leads to the separation of the main fluids and the formation of liquid accumulations in the lower generatrix and gas caps in the transfer points of the system.
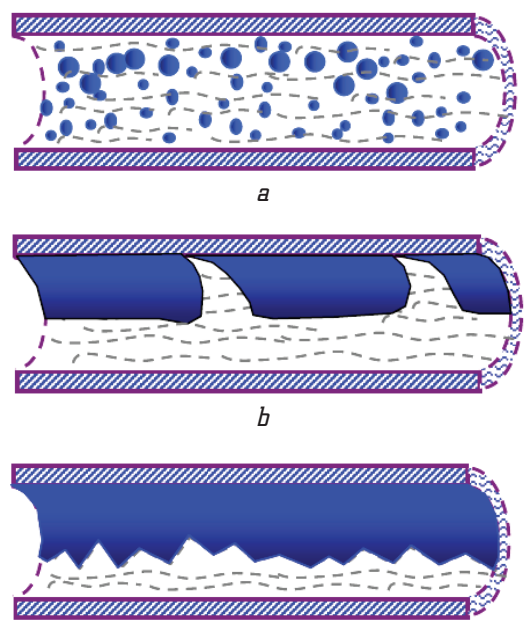

c

Fig. 2. Characteristics of the movement of mixtures at various stages of development: $a$ - early stage; $b$ - stage of production stabilization (intensification); $c$ - late stage

In fact, the main task of the algorithm is to determine what type of structural flow the researcher is dealing with, and also by the quantitative content of a liquid in a gas or gas in a liquid, to determine the uniformity of flow.

The definition of the transfer mode of the liquid-gas mixture on the ascending pipeline is performed in the following sequence [22]:

a) $V^{*}$ value is determined:

$$
\begin{aligned}
& V^{*}=\left(8.2-0.017 \cdot \bar{\mu}^{-0.6}\right) \cdot\left(R e_{2} \cdot F r_{c} \cdot \frac{\rho_{2}}{\rho_{1}-\rho_{2}}\right)^{-1 / 3} \times \\
& \times \exp \left[(8+62 \cdot \bar{\mu}) \cdot \beta_{1}\right],
\end{aligned}
$$

where $\bar{\mu}=\mu_{2} / \mu_{1}-$ reduced viscosity; $\mu_{1}, \mu_{2}-$ dynamic viscosity of the liquid and gas phase, respectively, Pa.s; $\beta_{1}=Q_{1} / Q_{c}-$ content of liquid in the stream of liquid-gas mixture; $Q_{1}, Q_{c}-$ volumetric flow rates of the liquid and the mixture, respectively, $\mathrm{m}^{3} / \mathrm{s} ; \rho_{1}, \rho_{2}$ - density of liquid and gas phases, $\mathrm{kg} / \mathrm{m}^{3} ; \operatorname{Re}_{2}=\left(\rho_{2} \cdot w_{c} \cdot D\right) / \mu_{2}$ - Reynolds number, describes the mode of motion of the gas in the mixture; $w_{c}=4 Q_{c} / \pi D^{2}-$ velocity of the liquid-gas mixture, $\mathrm{m} / \mathrm{s}$; $F r_{c}=w_{c}^{2} / g D$ - Froude criterion for liquid-gas mixture.

When $V^{*} \leq 1$ - flow mode is ring; $V^{*}>1$ - flow mode is plug or stratified;

b) froude criterion $\mathrm{Fr}^{*}$ is determined by the content of gas and liquid in the mixture:

$$
F r^{*}=\left(0.2+\frac{2 \cdot \sin \alpha_{\text {max }}}{\lambda_{p}}\right) \cdot \beta_{1}^{-2} \cdot \exp \left(-2.5 \cdot \beta_{2}\right),
$$

where $\beta_{2}=1-\beta_{1}-$ the gas content in the stream of liquidgas mixture; $\alpha_{\max }-$ the maximum inclination angle of the descending sections of the pipeline's equivalent route, rad; $\lambda_{p}-$ hydraulic resistance coefficient, which is determined from the system of equations:

$$
\left\{\begin{array}{l}
\lambda_{p}=\frac{2 \sin \alpha \cdot g \cdot D}{\omega_{p}^{2}}, \\
\lambda_{p}=0.067 \cdot\left(\frac{158}{R e_{p}}+\frac{2 \cdot K_{e q}}{D}\right)^{0.2},
\end{array}\right.
$$

where $R e_{p}=\left(\rho_{1} \cdot w_{p} \cdot D\right) / \mu_{1}-$ Reynolds number, describes the mode of motion only of the liquid component; $K_{e q}-$ equivalent roughness, $\mathrm{m} ; w_{p}=4 Q_{1} / \pi D^{2}-$ fluid velocity, $\mathrm{m} / \mathrm{s}$.

At $F r_{c}>F r^{*}$ on this site of the pipeline the plug mode of a stream of a mix takes place. At $F r_{c}<F r^{*}$ at this section of the pipeline there is a stratified mixture.

The pressure drop in the calculated area when the ring and plug flow in the descending areas is determined by the formula [23]:

$$
\frac{\Delta P}{\Delta L}=\lambda_{c} \cdot \frac{w_{c}^{2}}{2 D} \cdot\left(\frac{\beta_{1}^{2}}{\phi_{1}} \rho_{1}+\frac{\beta_{2}^{2}}{\phi_{2}} \rho_{2}\right)-\left(\phi_{1} \rho_{1}+\phi_{2} \rho_{2}\right) \cdot g \cdot|\sin \alpha|,
$$

where $\phi_{1}-$ the actual volumetric content of fluid in the flow (the part of the pipe that is occupied by the fluid); $\lambda_{c}-$ coefficient of hydraulic resistance.

The value $\phi_{1}$ for a descending flow of a liquid-gas mixture in a ring mode is determined by the formula:

$$
\begin{aligned}
& \phi_{1}=\left[1-\frac{1}{1+3.84 \cdot 10^{-6} \cdot\left[\operatorname{Re}_{1} F r_{c}\left(\frac{\rho_{2}}{\rho_{1}-\rho_{2}}\right)\right] \cdot|\sin \alpha|^{-1.66}}\right] \times \\
& \times \frac{5.5 \cdot \sqrt{100 \cdot \beta_{1}}}{\left[\operatorname{Re}_{1} F r_{c}\left(\frac{\rho_{2}}{\rho_{1}-\rho_{2}}\right)\right]^{\frac{1}{3}}}
\end{aligned}
$$

where $R e_{1}=\left(\rho_{1} \cdot w_{c} \cdot D\right) / \mu_{1}-$ the Reynolds number, which describes the mode of motion of the fluid in the mixture.

The value $\phi_{1}$ for the descending plug flow is determined by the formula:

$$
\phi_{1}=1-K \cdot \beta_{2},
$$

where $K$ - coefficient taking into account the effect of viscosity of the liquid. 


$$
\begin{aligned}
& K=0.35+1.4 \cdot \sqrt[4]{\bar{\mu}} \text { at } \bar{\mu} \leq 0.01, \\
& K=0.77+0.23 \cdot \sqrt{\bar{\mu}} \text { at } \bar{\mu}>0.01 .
\end{aligned}
$$

The actual coefficient of hydraulic resistance in the ring mode is determined by the formula:

$$
\lambda_{c}^{a}=\lambda \cdot \psi
$$

where $\lambda$ - coefficient of hydraulic resistance when a homogeneous fluid flows.

$$
\lambda=0.067 \cdot\left(\frac{158}{R e_{1}}+\frac{2 \cdot K_{e q}}{D}\right)^{0.2},
$$

where $\psi$ - the combined coefficient of hydraulic resistance.

$$
\begin{aligned}
& \psi=1+0.0031 \cdot\left(R e_{2} F r_{c} \cdot \frac{\rho_{1}-\rho_{2}}{\rho_{2}}\right)^{\frac{1}{3}} \times \\
& \times \exp \left[-15 \cdot\left(\bar{\rho}+\beta_{1}\right)\right] \cdot \sqrt{100 \cdot \beta_{1}} .
\end{aligned}
$$

In case of a plug-flow mode, the actual hydraulic resistance coefficient is determined by the formula:

$$
\lambda_{c}^{a}=\left((3-1.26 \cdot a)-2 \cdot a \cdot \lg \left(\frac{2 K_{e q}}{D}+\frac{18.7}{R e_{1} \cdot \sqrt{\lambda}}\right)\right)^{-2},
$$

where

$$
a=\sqrt{\frac{1}{1+18.8 \cdot(1-K)^{2} \cdot\left(\beta_{2} / \beta_{1}\right)^{2}}} ;
$$

$K$ is determined by the formulas (11), (12)

In the stratified flow regime, the hydraulic pressure drop for the descending section is determined by the formula [24]:

$$
\frac{\Delta P}{\Delta L}=\lambda_{2} \cdot \frac{\rho_{2} \cdot w_{2}^{2}}{2 \cdot D_{\Gamma}}-\rho_{2} \cdot g \cdot|\sin \alpha| .
$$

Hydraulic diameter:

$$
\begin{aligned}
& D_{H}=D \cdot \sqrt{\phi_{2}}, \\
& w_{2}=\frac{4 \cdot Q_{2}}{\pi \cdot D_{\Gamma}^{2}}, \quad \phi_{2}=\frac{\theta-\sin \theta \cdot \cos \theta}{\pi},
\end{aligned}
$$

where $Q_{2}$ - the volumetric gas flow rate, $\mathrm{m}^{3} / \mathrm{s} ; \theta$ - half of the central angle to the liquid segment, rad (Fig. 3).

The actual fluid content is determined by the formula:

$$
\phi_{1}=2.63 \cdot \sqrt[3]{F r_{c} \cdot \frac{\rho_{2}}{\rho_{1}-\rho_{2}} \cdot \beta_{1}^{2} \cdot(0.02+\sqrt{|\sin \alpha|})^{-1}} .
$$

Actual hydraulic resistance coefficient:

$$
\lambda_{c}^{a}=0.067\left(\frac{158}{R e_{H}}+\frac{2 K_{e q}}{D_{H}}\right)^{0.2}
$$

where $R e_{H}=\left(4 \cdot Q_{2} \cdot \rho_{2}\right) /\left(D_{H} \cdot \mu_{2} \cdot \theta\right)-$ the Reynolds number, which describes the gas flow regime for the hydraulic diameter.

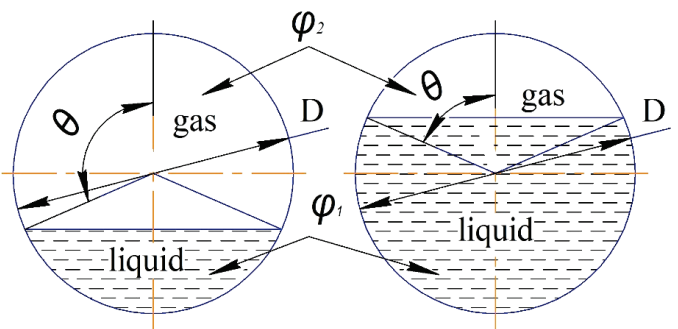

Fig. 3. Distribution diagram of liquid and gas in the pipe to the condensate line

Since, by their nature, the flow movement structure can't be expanded in ascending sections, the determination of the transfer mode of the liquid-gas mixture in the ascending section of the pipeline is based on the determination of (5) $V^{*}$ :

- at $V^{*} \leq 1$ - there is a ring flow of the mixture;

- at $V^{*} \leq 1$ - there is a plug mode of the mixture flow is realized.

Hydraulic calculation of the ascending pipeline section is made according to the formula:

$$
\frac{\Delta P}{\Delta L}=\lambda_{c} \cdot \frac{w_{c}^{2}}{2 D}\left(\frac{\beta_{1}^{2}}{\phi_{1}} \rho_{1}+\frac{\beta_{2}^{2}}{\phi_{2}} \rho_{2}\right)+\left(\phi_{1} \rho_{1}+\phi_{2} \rho_{2}\right) \cdot g \cdot \sin \alpha
$$

The value $\phi_{1}$ for the ascending ring flow is determined by the formula:

$$
\phi_{1}=\frac{\phi_{1}^{*}}{1+200 \cdot \beta_{1}}+\frac{5.5 \cdot \sqrt{100 \cdot \beta_{1}}}{\left(\operatorname{Re}_{1} F r_{c} \cdot \frac{\rho_{2}}{\rho_{1}-\rho_{2}}\right)^{\frac{1}{3}}},
$$

where $\phi_{1}^{*}$ - the actual volumetric content of the liquid at zero fluid flow:

$$
\phi_{1}^{*}=0.0053 \frac{3.3-W_{\alpha}}{\left(\operatorname{Re}_{1} \cdot F r_{c} \frac{\rho_{2}}{\rho_{1}-\rho_{2}}\right)^{\frac{1}{3}}} \text { at } W_{\alpha}<3.3 \text {, }
$$

$\phi_{1}^{*}=0$ at $W_{\alpha} \geq 3.3$,

where

$$
W_{\alpha}=w_{c}\left(\frac{\rho_{1}-\rho_{2}}{\sigma \cdot g \cdot \sin \alpha}\right)^{0.25} \cdot\left(\frac{\rho_{2}}{\rho_{1}}\right)^{0.5},
$$

$\sigma$ - the surface tension force of the main component of the liquid-gas mixture, $\mathrm{N} / \mathrm{m}$.

For the ascending cork flow, the actual gas content is determined by the formula:

$$
\phi_{2}=K \cdot\left[1-\exp \left(-4.4 \cdot \sqrt{\frac{F r_{c}}{F r_{\alpha}}}\right)\right] \cdot \beta_{2} .
$$


$F r_{\alpha}$ value is determined by the relationship:

$$
\begin{aligned}
& F r_{\alpha}=1150 \cdot \bar{\mu}^{0.79} \text { at } \bar{\mu}<0.001, \\
& F r_{\alpha}=9.8 \cdot \bar{\mu}^{0.1} \text { at } \bar{\mu} \geq 0.001 .
\end{aligned}
$$

The value of $K$ is determined by formulas (11) and (12).

With an ascending ring flow of the mixture, the value $\lambda_{c}$ is determined by formulas (11)-(13). With an ascending plug flow, the value $\lambda_{c}$ is determined by formula (14).

6.2. Analysis of operating modes of gas pipelines. The operating modes of the gas production system determine the dynamism of its operating modes, which lead to the movement of liquid formations in the cavity of pipelines, which is especially characteristic of the final stage of field development. For the evaluation, a system of inter-field transportation of products between the installations of the fields at the final stage of operation was chosen. In fact, as can be seen from Table 1 based on the processing of the actual operation mode of gas condensate lines with significant gas content in the flow, the structural currents follow each other in length and lead to a constant transition of one form to another.

As a result, this leads to an unpredictable rapid release of liquid, because in order to prevent this phenomenon, it is necessary to introduce measures to divert water from the cavity of pipelines. It is possible to estimate the volume of this instantaneous surge due to the movement of liquid plugs under conditions of a decrease in the operating pressure in the system between industrial pipelines or changes in other operating conditions (Table 2).

Table 1

\begin{tabular}{|c|c|c|c|c|c|c|c|c|c|}
\hline \multicolumn{5}{|c|}{ Pipeline name } & \multicolumn{5}{|c|}{$\begin{array}{c}\text { Pipeline for pumping multiphase mixtures (condensate, water, oil, gas) from complex } \\
\text { gas treatment units (CGTU) Komisnia to CGTU Yarivska }\end{array}$} \\
\hline \multicolumn{5}{|c|}{ Measured parameters of hydraulic state } & \multicolumn{5}{|c|}{ 9:00 May 1, 2017 - 9:00 May 2, 2017} \\
\hline \multicolumn{5}{|c|}{ The period during which studies were conducted } & \multicolumn{5}{|c|}{1 day from 9:00 on May 1, 2017} \\
\hline \multicolumn{5}{|c|}{ The mass of the mixture at the beginning of the pipeline, $\mathrm{kg} / \mathrm{h}$} & \multicolumn{5}{|c|}{3387} \\
\hline \multicolumn{5}{|c|}{ Initial pressure, $\mathrm{kg} / \mathrm{cm}^{2}$} & \multicolumn{5}{|c|}{19.39} \\
\hline \multicolumn{5}{|c|}{ Final pressure, kgf/ $\mathrm{cm}^{2}$} & \multicolumn{5}{|c|}{18.12} \\
\hline \multicolumn{5}{|c|}{ Initial temperature, ${ }^{\circ} \mathrm{C}$} & \multicolumn{5}{|c|}{23.28} \\
\hline \multicolumn{5}{|c|}{ Final temperature, ${ }^{\circ} \mathrm{C}$} & \multicolumn{5}{|c|}{12.23} \\
\hline \multicolumn{5}{|c|}{ The density of the mixture in the initial section, $\mathrm{kg} / \mathrm{m}^{3}$} & \multicolumn{5}{|c|}{695.6} \\
\hline \multicolumn{5}{|c|}{ The density of the mixture in the final section, $\mathrm{kg} / \mathrm{m}^{3}$} & \multicolumn{5}{|c|}{702.35} \\
\hline \multirow{3}{*}{\multicolumn{5}{|c|}{ Technical specifications }} & \multirow{2}{*}{$\begin{array}{c}\text { Real } \\
\text { length, m }\end{array}$} & \multirow{2}{*}{\multicolumn{2}{|c|}{ Internal diameter, mm }} & \multicolumn{2}{|c|}{$\begin{array}{c}\text { Number } \\
\text { of sections - } 18\end{array}$} \\
\hline & & & & & & & & Ascending & Descending \\
\hline & & & & & 27504.6 & $\begin{array}{l}143 \mathrm{~mm} \text { at the site } \\
86 \mathrm{~mm}-\text { further to }\end{array}$ & $\begin{array}{l}\text { to } 14.4 \mathrm{~km} \text {, } \\
\text { the end point }\end{array}$ & 4 & 14 \\
\hline \multicolumn{10}{|c|}{ Detailing by sections } \\
\hline $\begin{array}{l}\text { No. } \\
\text { sec. }\end{array}$ & Type & Length, m & $\begin{array}{l}\text { Internal di- } \\
\text { ameter, mm }\end{array}$ & $\begin{array}{l}\text { Tilt angle, } \\
\text { deg }\end{array}$ & $\begin{array}{l}\text { Flow } \\
\text { structure }\end{array}$ & $\begin{array}{l}\text { The speed of movement of } \\
\text { the gas-liquid mixture, } \mathrm{m} / \mathrm{s}\end{array}$ & $\begin{array}{c}\text { Section passage } \\
\text { time by the liquid, } \mathrm{s}\end{array}$ & \multicolumn{2}{|c|}{$\begin{array}{l}\text { The coefficient of area } \\
\text { hydraulic resistance }\end{array}$} \\
\hline 1 & $a s c$ & 500.009 & 143.0 & 0.005999928 & stratified & 0.088 & 5695.039129 & \multicolumn{2}{|c|}{0.031642807} \\
\hline 2 & asc & 1500.00133 & 143.0 & 0.001333333 & wave plug & 0.088 & 17084.82505 & 0.0313 & 339705 \\
\hline 3 & des & 400.211 & 143.0 & 0.032488565 & stratified & 0.088 & 4558.354773 & 0.0320 & 032459 \\
\hline 4 & des & 2000.025 & 143.0 & 0.004999958 & stratified & 0.088 & 22780.03123 & $0.031 \mathrm{E}$ & 619386 \\
\hline 5 & des & 800.3905 & 143.0 & 0.031239833 & stratified & 0.088 & 9116.346677 & 0.0320 & 039302 \\
\hline 6 & $a s c$ & 4800.015 & 143.0 & 0.002499995 & wave plug & 0.088 & 54671.56241 & 0.0315 & 516794 \\
\hline 7 & des & 500.014 & 143.0 & 0.002399995 & stratified & 0.088 & 5694.953022 & 0.0315 & 515737 \\
\hline 8 & des & 1100.0003 & 143.0 & 0.000727273 & stratified & 0.088 & 12528.86388 & 0.0312 & 281565 \\
\hline 9 & des & 600.053 & 143.0 & 0.013332543 & stratified & 0.088 & 6834.531378 & 0.0318 & 894419 \\
\hline 10 & des & 1000.05 & 143.0 & 0.009999667 & stratified & 0.088 & 11390.44272 & 0.0318 & 834775 \\
\hline 11 & des & 800.25 & 143.0 & 0.024994794 & stratified & 0.088 & 9114.745617 & 0.0320 & 047527 \\
\hline 12 & des & 402.305 & 143.0 & 0.107088749 & stratified & 0.088 & 4582.198524 & 0.0323 & 395907 \\
\hline 13 & $a s c$ & 9800.074 & 86.0 & 0.003877532 & wave plug & 0.243 & 40371.33017 & 0.0272 & 279678 \\
\hline 14 & des & 900.067 & 86.0 & 0.012221614 & stratified & 0.243 & 3707.820177 & 0.027 & 86271 \\
\hline 15 & des & 800.01 & 86.0 & 0.004999958 & stratified & 0.243 & 3295.635209 & 0.0274 & 420804 \\
\hline 16 & des & 801.05 & 86.0 & 0.0512052 & stratified & 0.243 & 3299.919218 & 0.0284 & 486385 \\
\hline 17 & $a s c$ & 200.068 & 86.0 & 0.025994144 & wave plug & 0.243 & 824.1769342 & 0.028 & 221896 \\
\hline 18 & des & 600 & 86.0 & 0.000333333 & stratified & 0.243 & 2471.695648 & 0.0257 & 728953 \\
\hline Genere & and we & hted average in & cators & & & $\begin{array}{l}0.088-\text { at the initial sec- } \\
\text { tion, } 0.243-\text { at the final } \\
\text { section }\end{array}$ & $\begin{array}{c}218022.5 \\
\text { (2 days, } 12 \text { hours, } \\
32 \text { minutes) }\end{array}$ & $\begin{array}{r}0.032-\text { a } \\
\text { section, } 0.0 \\
\text { final s }\end{array}$ & $\begin{array}{l}\text { at the initial } \\
227 \text { - at the } \\
\text { section }\end{array}$ \\
\hline
\end{tabular}

Baseline data for determining hydraulic resistance coefficients and flow patterns 
Table 2

The time required to move the fluid plug [25]

\begin{tabular}{|c|c|c|c|c|}
\hline Level & $\begin{array}{c}\text { Volume of a } \\
\text { liquid plug, } \mathrm{m}^{3}\end{array}$ & $\begin{array}{c}\text { Section } \\
\text { length, } \mathrm{m}\end{array}$ & $\begin{array}{c}\text { Linear } \\
\text { speed, } \mathrm{m} / \mathrm{s}\end{array}$ & $\begin{array}{c}\text { The time required to } \\
\text { move th plug, min }\end{array}$ \\
\hline Minimum & 15.0 & 7000.0 & 4.0 & 30 \\
\hline Average & 15.0 & 7000.0 & 16.0 & 8 \\
\hline Maximum & 15.0 & 7000.0 & 28.0 & 4 \\
\hline
\end{tabular}

The time required for this plug to be moved by the gas flow from the lowered position of the pipeline to the entrance to the separation equipment is presented in Table 2. For its evaluation, the following calculated data are used:

- the maximum speed is formed in the pipeline when the operating pressure drops to 12 at $-28 \mathrm{~m} / \mathrm{s}$; - the maximum speed is formed in the pipeline when operating at a pressure of 24 at $-4 \mathrm{~m} / \mathrm{s}$; - the average speed formed in the pipeline when the operating pressure decreases to 12 at $-16 \mathrm{~m} / \mathrm{s}$.

As can be seen from the Table 2, the expected time of fluid intake will begin 4 minutes after the working pressure is reduced and will end after 30 minutes, during which $15 \mathrm{~m}^{3}$ of water will be picked up in the separators. If the volume of such a salvo emission is significantly larger than the design of the input separator, this will lead to an emergency stop of the equipment.

Mostly salvo emissions of the liquid are provoked by a sharp change in the pressure mode of operation and can be monitored with a pressure drop in the pipeline, namely by comparing its optimal (nominal) values and actual parameters.

The actual values of pressure and temperature at the initial, final and intermediate points of the pipeline section are simultaneously selected according to the indications of questionnaires or measurement data. Chromatographic analysis allows to remove the gas-condensate characteristic in the case of continuous polling with flow meters [26].

For each specific section of the pipeline, in accordance with its orientation in space, according to the above algorithm, the structure (type) of the liquid-gas flow is selected and the corresponding parameters of the hydraulic state are calculated. The actual hydraulic condition of the ascending and descending sections of pipelines is evaluated according to the actual coefficient of hydraulic resistance, which is calculated in accordance with the structure of the liquid-gas flow according to an algorithm.

The actual and nominal pressure loss for the present hydraulic condition of the pipeline by adding them to all the studied areas is calculated:

$$
\Delta P=\left(\sum_{i=1}^{n_{\text {asc }}} \frac{\Delta P}{\Delta L}+\sum_{i=1}^{n_{\text {des }}} \frac{\Delta P}{\Delta L}\right) L
$$

Using the values of the initial working pressure and the calculated pressure loss, the calculated final pressure is determined and compared with the measured values according to questionnaires or instrument measurements. If the value of the calculated final pressure is higher than the measured one, the formation of contaminants is recorded at lower points of the pipeline route.

An example of the calculation is given for the existing section of the pipeline pumping gas production between two installations. The results of the comparison of the measured value of the final pressure and its calculated value are summarized in Table 3.

Table 3

on pressure losses due to hydraulic resistance of the
in the investigated period from 01 to 14 May 2017

\begin{tabular}{|c|c|c|c|c|c|}
\hline $\begin{array}{l}\text { ass of the } \\
\text { supplied } \\
\text { mixture, } \\
\mathrm{kg} / \mathrm{h}\end{array}$ & $\begin{array}{c}\text { Initial } \\
\text { pres- } \\
\text { sure, } \\
\mathrm{kgf} / \mathrm{cm}^{2}\end{array}$ & $\begin{array}{c}\text { Hydraulic } \\
\text { (calculated) } \\
\text { losses, } \\
\text { kgf/cm² }\end{array}$ & $\begin{array}{c}\text { Final } \\
\text { pressure } \\
\text { (calculated), } \\
\mathrm{kgf} / \mathrm{cm}^{2}\end{array}$ & $\begin{array}{c}\text { Final } \\
\text { pressure } \\
\text { (measured), } \\
\text { kgf/cm }{ }^{2}\end{array}$ & $\begin{array}{l}\text { Difference in } \\
\text { the values of } \\
\text { the final pres- } \\
\text { sure, } \mathrm{kgf} / \mathrm{cm}^{2}\end{array}$ \\
\hline 3387 & 19.60 & 1.01 & 18.59 & 18.27 & 0.32 \\
\hline 3215 & 19.42 & 1.01 & 18.41 & 18.20 & 0.21 \\
\hline 3254 & 19.46 & 1.01 & 18.45 & 18.19 & 0.26 \\
\hline 3255 & 19.22 & 1.01 & 18.21 & 17.95 & 0.26 \\
\hline 3406 & 19.66 & 1.01 & 18.65 & 18.22 & 0.43 \\
\hline 3365 & 19.50 & 1.00 & 18.50 & 18.17 & 0.33 \\
\hline 3356 & 19.32 & 1.00 & 18.32 & 18.04 & 0.28 \\
\hline 3352 & 19.01 & 1.01 & 18.00 & 17.67 & 0.33 \\
\hline 3465 & 19.51 & 1.01 & 18.50 & 18.04 & 0.46 \\
\hline 3451 & 19.72 & 1.00 & 18.72 & 18.29 & 0.43 \\
\hline 3420 & 19.46 & 0.99 & 18.47 & 18.07 & 0.40 \\
\hline 3432 & 19.41 & 1.00 & 18.41 & 17.97 & 0.44 \\
\hline 3506 & 19.61 & 1.00 & 18.61 & 18.03 & 0.58 \\
\hline 3521 & 20.11 & 1.00 & 19.11 & 18.47 & 0.64 \\
\hline 84.6 & 19.51 & 1.00 & 18.51 & 18.13 & 0.38 \\
\hline
\end{tabular}

Note: * - salvo fluid redistribution various patterns of movement of the gas-liquid mixture in the cavity of the pipeline leads to a volatile redistribution of fluid at a certain point in time due to a change in the pressure mode of operation. This necessitates the use of various methods of removal of pollution, and for certain pipelines requires an integrated approach to solving the issue of removal of pollution from the cavity of pipelines.

6.3. The construction of the algorithm for selecting the optimal method of removal of contaminants from the pipeline cavity. From the choice of the method of removal of fluid with the presented algorithm, the hydraulic state of the collection systems and inter-industrial transportation of products with different gas content with a total length of about 12.0 thousand $\mathrm{km}$ were analyzed, which were divided into three groups:

1) for deposits at an early stage of operation - $2 \%$ of the total;

2) for deposits with stabilized (or smoothly falling) production $-24 \%$ of the total; 
3) for deposits at the final stage of operation - $74 \%$ of the total.

It is established that the choice of the optimal method of cleaning the internal cavity of the pipeline depends on the following main factors:

- structural form of the mixture movement, during

pumping of which pollution is formed;

- true gas content, which determines the homogeneity

of the gas or liquid flow and determines the type of pipeline with which the researcher is dealing;

- hydraulic condition, necessitates the removal of fluid.

Based on these calculation results, the algorithm for selecting the optimal method for cleaning the pipeline cavity from accumulated pollution results in the following sequence presented in Table 4.

In fact, for the same pipeline, it is possible to apply various methods of drainage, eliminating the obviously ineffective, using the data of Table 4 and an algorithm for evaluating the structural forms of motion and the hydraulic state of pipelines pumping a multiphase medium is presented.

The choice of the optimal measure should be based on the assessment of the influence of the three factors listed

above, on the basis of its action and based on a mathematical model of the change in the structural form of the gas-liquid mixture or pollution, which is confirmed by experimental studies.

As can be seen from the presented analysis, the most optimal method of cleaning the gas pipelines of the collection systems and the inter-industrial transportation of natural and petroleum gas is the transmission of pistons, since they can be used for any periods of field development and the corresponding structural flow streams. However, refining pistons have significant limitations in the use of mature gas fields for gas collection systems, since these systems are equipped with non-corrugated fittings, and the condition of the internal surface of pipelines is eroded and worn. For depleted fields, the optimal point is the selection of liquids, which requires the installation of a large number of traps [14].

The optimal solution is the development and application of new designs of cleaning pistons. One of which is elastic models of pistons, which can undergo both local narrowing and local resistance in the form of non-curved fittings.

Table 4

Algorithm for choosing the best ways to drain fluid from the pipeline cavity

1 Definition of flow patterns

\begin{tabular}{|c|c|c|c|c|c|c|c|c|c|}
\hline \multicolumn{4}{|c|}{$\begin{array}{l}1 \text { Stratified with a smooth surface and the formation of } \\
\text { waves when changing the technological operation mode }\end{array}$} & \multicolumn{3}{|c|}{$\begin{array}{l}2 \text { Plug typical for ascending areas or salvo emis- } \\
\text { sions of liquid when changing operation modes }\end{array}$} & \multicolumn{3}{|c|}{$\begin{array}{l}3 \text { Ring typical for plumes of flowing wells or } \\
\text { gas pipelines with full load }\end{array}$} \\
\hline \multicolumn{10}{|c|}{2 Determination of structure homogeneity (phase mode and main phase) by true gas content } \\
\hline $\begin{array}{l}1 \text { gas con- } \\
\text { tent } \rightarrow 1 \text { : gas } \\
\text { pipeline with } \\
\text { liquid in low } \\
\text { places }\end{array}$ & $\begin{array}{l}2 \text { gas content } \rightarrow \\
0 \text { : product } \\
\text { pipeline with the } \\
\text { formation of gas } \\
\text { caps in trans- } \\
\text { shipment points }\end{array}$ & $\begin{array}{l}3 \text { gas content } \\
\text { in } 0.6-0.99 \text { : } \\
\text { a product } \\
\text { pipeline with } \\
\text { a stratified flow, } \\
\text { the lower one } \\
\text { being occupied } \\
\text { by a liquid, the } \\
\text { upper one by } \\
\text { a gas }\end{array}$ & $\begin{array}{l}1 \text { ga } \\
1: \text { ge } \\
\text { with } \\
\text { sions } \\
\text { from }\end{array}$ & $\begin{array}{l}\text { as content } \rightarrow \\
\text { jas pipeline } \\
\text { salvo emis- } \\
\text { is of liquid } \\
\text { n low places }\end{array}$ & $\begin{array}{l}2 \text { gas con- } \\
\text { tent } \rightarrow 0 \text { : } \\
\text { product pipe } \\
\text { with gas caps } \\
\text { that cause } \\
\text { pressure pulsa- } \\
\text { tions }\end{array}$ & $\begin{array}{l}3 \text { gas content } \\
\text { in } 0.6-0.99: \\
\text { product pipeline } \\
\text { with ascen- } \\
\text { ding sections } \\
\text { filled with gas, } \\
\text { through which } \\
\text { the liquid is } \\
\text { pushed in the } \\
\text { form of stop- } \\
\text { pers }\end{array}$ & $\begin{array}{l}1 \text { gas con- } \\
\text { tent } \rightarrow 1: \\
\text { gas pipeline } \\
\text { in which } \\
\text { a small } \\
\text { amount } \\
\text { of liquid } \\
\text { moves in } \\
\text { the form of } \\
\text { a film }\end{array}$ & $\begin{array}{l}2 \text { gas } \\
\text { content } \rightarrow \\
0: \text { product } \\
\text { pipeline in } \\
\text { which gas is } \\
\text { concentrated } \\
\text { in a liquid } \\
\text { stream in } \\
\text { the form of } \\
\text { bubbles }\end{array}$ & $\begin{array}{l}3 \text { gas content } \\
\text { of } 0.6-0.99: \\
\text { a gas pipeline } \\
\text { (emergency mode } \\
\text { close to a water } \\
\text { hammer) or an } \\
\text { ascending section } \\
\text { of a product pipe- } \\
\text { line in which a } \\
\text { gas is surrounded } \\
\text { by a ring of liquid }\end{array}$ \\
\hline
\end{tabular}

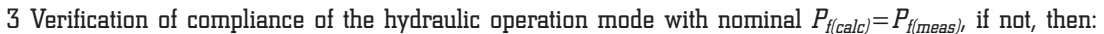

\begin{tabular}{|c|c|c|c|c|c|c|c|c|}
\hline $\begin{array}{l}\text { Fluid forms } \\
\text { pollution in } \\
\text { lower trans- } \\
\text { fer points } \\
\text { (natural fluid } \\
\text { traps) }\end{array}$ & $\begin{array}{l}\text { Gas forms a gas } \\
\text { cap in the upper } \\
\text { transfer points of } \\
\text { the pipeline }\end{array}$ & $\begin{array}{l}\text { Volume of } \\
\text { a more dense } \\
\text { liquid (water) } \\
\text { is formed } \\
\text { at the lower } \\
\text { transfer points; } \\
\text { a gas cap } \\
\text { occurs at the } \\
\text { upper transfer } \\
\text { points }\end{array}$ & $\begin{array}{l}\text { Salvo removal of } \\
\text { the liquid from } \\
\text { the lowered point } \\
\text { of the pipeline } \\
\text { occurs }\end{array}$ & $\begin{array}{l}\text { The estab- } \\
\text { lished gas cap } \\
\text { determines } \\
\text { the mode of } \\
\text { operation of } \\
\text { the pumping } \\
\text { equipment in } \\
\text { cycles }\end{array}$ & $\begin{array}{l}\text { The liquid com- } \\
\text { ponent moves } \\
\text { in the form of a } \\
\text { plug due to the } \\
\text { ascending por- } \\
\text { tion, changing } \\
\text { the structure to } \\
\text { layered in the } \\
\text { descending }\end{array}$ & $\begin{array}{l}\text { The liquid } \\
\text { provides } \\
\text { additional } \\
\text { resistance } \\
\text { during } \\
\text { transfer, } \\
\text { moving in } \\
\text { the form of } \\
\text { a film }\end{array}$ & $\begin{array}{l}\text { Gas reduces } \\
\text { the viscosity } \\
\text { of the mix- } \\
\text { ture, reduc- } \\
\text { ing energy } \\
\text { consumption } \\
\text { for pumping }\end{array}$ & $\begin{array}{l}\text { Ring traffic is } \\
\text { formed on the } \\
\text { ascending sec- } \\
\text { tions, and cork } \\
\text { on the down ones }\end{array}$ \\
\hline \multicolumn{9}{|c|}{4 The choice of the type of method of pollution removal from the pipeline cavity and a description of the operation principle } \\
\hline $\begin{array}{l}\text { periodic - } \\
\text { removal of } \\
\text { fluid from the } \\
\text { cavity }\end{array}$ & $\begin{array}{l}\text { periodic - gas } \\
\text { release from } \\
\text { gas cap }\end{array}$ & $\begin{array}{l}\text { periodic - } \\
\text { removal of the } \\
\text { most dense } \\
\text { pollution }\end{array}$ & $\begin{array}{l}\text { periodic - removal } \\
\text { of fluid from the } \\
\text { cavity }\end{array}$ & $\begin{array}{l}\text { periodic - gas } \\
\text { release from } \\
\text { gas cap }\end{array}$ & $\begin{array}{l}\text { periodic - } \\
\text { removal of the } \\
\text { most dense } \\
\text { pollution }\end{array}$ & \begin{tabular}{|l|} 
permanent - \\
liquid film \\
break and \\
its removal
\end{tabular} & $\begin{array}{l}\text { for plumes } \\
\text { of wells to } \\
\text { remove gas } \\
\text { is impractical }\end{array}$ & $\begin{array}{l}\text { permanent - } \\
\text { liquid film break } \\
\text { and its removal }\end{array}$ \\
\hline \multicolumn{9}{|c|}{5 Definition of the list of methods of pollution removal } \\
\hline $\begin{array}{l}1 \text { Drain tube } \\
2 \text { High-speed } \\
\text { flow } \\
3 \text { Piston skip }\end{array}$ & $\begin{array}{l}1 \text { Drain tube } \\
\text { for venting gas } \\
\text { to the following } \\
\text { areas } \\
2 \text { Piston skip }\end{array}$ & $\begin{array}{l}1 \text { Drain tube } \\
2 \text { Piston skip }\end{array}$ & $\begin{array}{l}1 \text { Drain tube } \\
2 \text { High-speed flow } \\
3 \text { Piston skip }\end{array}$ & $\begin{array}{l}1 \text { Drain tube } \\
\text { for venting gas } \\
\text { to the following } \\
\text { areas }\end{array}$ & $\begin{array}{l}1 \text { Drain tube } \\
2 \text { Piston skip }\end{array}$ & $\begin{array}{l}1 \text { Drip on } \\
\text { the prin- } \\
\text { ciple of the } \\
\text { expansion } \\
\text { chamber }\end{array}$ & $\begin{array}{l}1 \text { Piston } \\
\text { skip }\end{array}$ & $\begin{array}{l}1 \text { Drip on the } \\
\text { principle of } \\
\text { the expansion } \\
\text { chamber }\end{array}$ \\
\hline
\end{tabular}




\section{SWOT analysis of research results}

Strengths. Conducting periodic studies of the state of industrial pipelines excludes additional costs for the company to use inefficient methods for cleaning the system.

As a result of research to determine the structure of the form of movement and the actual hydraulic state of industrial pipelines pumping a multiphase medium, will allow to determine the sequence of choosing the best ways to drain fluid from the cavity of the pipeline in accordance with the principle of their action. Such a sequence will make it possible to discard the obviously ineffective methods for one or another type of industrial pipelines from further analysis.

Weaknesses. The research results are somewhat different from the actual data.

Opportunities. The need to create composite materials that will be able to keep the shape, moving in the form of a tube through the cavity of the pipeline.

Threats. The proposed algorithms require further research.

It has been determined that the best method of cleaning between industrial gas pipelines and well plumes is the transmission of cleaning pistons, the use of which, however, is limited for gas gathering systems of mature fields. Improvement of the design of such cleaning pistons is possible only due to a significant increase in their elasticity, which requires the creation of a composite material that would keep the shape moving in the form of a plug through the pipeline cavity with the optimal transit time between the initial and final points.

\section{Conclusions}

1. A study of the inter-field transportation of products between the installations of fields at the final stage of operation is carried out. The regularity of the flow structure transition in the stratified sections of the pipeline is established. It is also noted that when the flow went to the ascending section, the flow structure changed to wave or cork. It is noted that during the transition from the stratified flow into the wave or cork structure of flow, a slight decrease in the hydraulic resistance coefficient is observed in the investigated area. It is established that $85 \%$ of the pipelines of the oil and gas extraction system of mature fields transport raw materials in the form of a stratified structure.

2. An algorithm for determining the structural form of the gas-liquid flow is presented. An assessment of its type and homogeneity is carried out, the parameters of the hydraulic state (nominal and actual pressure losses during system operation) are determined. It is determined which processes cause different values of the final pressure in the studied pipeline sections. The proposed algorithm allows to clearly define the structure of the flow at a particular point in the system. Having the data calculated by the presented algorithm, it is possible to localize accumulations of pollution, as well as to prevent salvo emissions on separation equipment.

3. Based on the algorithm for determining the structural forms of the movement and the actual studies of the hydraulic condition of industrial pipelines, oil and gas production systems of various types of fields are formed, and a sequence is developed to select the optimal me- thods for removing fluid from the pipeline cavity. Such a sequence makes it possible to discard the obviously ineffective methods for one or another type of industrial pipelines from further analysis.

It is established that the choice of the optimal measure should be based on the assessment of the influence of such factors as are presented below:

- structural form of the mixture movement, during pumping of which pollution is formed;

- true gas content, which determines the homogeneity of the gas or liquid flow and determines the type of pipeline with which the researcher is dealing;

- hydraulic condition, which necessitates the removal of fluid.

\section{References}

1. Bratakh M. I., Ruzina I. M., Sobolieva A. V. Dynamika ridynnykh formuvan v porozhnyni mizhpromyslovoho hazoprovodu // Pytannia rozvytku hazovoi promyslovosti Ukrainy. 2009. Issue 37. P. 287-293.

2. Eaton B. A., Knowles C. R., Silberbrg I. H. The Prediction of Flow Patterns, Liquid Holdup and Pressure Losses Occurring During Continuous Two-Phase Flow In Horizontal Pipelines // Journal of Petroleum Technology. 1967. Vol. 19, Issue 6. P. 815-828. doi: http://doi.org/10.2118/1525-pa

3. Wellflo ${ }^{\mathrm{TM}}$ Petroleum engineering software user guide Software version 4.0. Weatherford. 374 p.

4. Beggs H. D. Production optimization using Nodal TM Analysis Tulsa: OGCI Publication, 1991. 197 p.

5. OLGA dynamic multiphase flow simulator. URL: https://www software.slb.com/products/olga

6. VSN 51-3-85. Proektirovanie promyslovykh stal'nykh truboprovodov. Moscow, 1985. $106 \mathrm{p}$.

7. Sposib vyznachennia hidravlichnoho stanu hazoprovodiv, yaki transportuiut hazoridynni sumishi: Pat. No. 36414 UA. MPK (2006) F17D / Diachuk V. V. et. al. No. u200806396; declareted: 14.05.2008; published: 27.10.2008. Bul. No. 20.

8. Charnyy I. A. Vliyanie rel'efa mestnosti i nepodvizhnykh vklyucheniy zhidkosti ili gaza na propusknuyu sposobnost' truboprovodov // Neftyanoe khozyaystvo. 1965. Issue 6. P. 51-55.

9. Gallyamov A. K. Vytesnenie vysokovyazkikh neftey i nefteproduktov v truboprovodakh // Gidrodinamika i fil'tratsiya odnofaznykh i mnogofaznykh potokov. Trudy MINKHiGP. «Nedra». 1972. Issue 101. P. 102-106.

10. Bratakh M. I. Sposib vyznachennia ob’yemu zabrudnen v porozhnyni hazoprovodiv, shcho transportuiut haz vlasnoho vydobutku // Zbirnyk naukovykh prats «DP Naukanaftohaz». 2007. Issue 5. P. 628-634.

11. SOU 09.1-30019775-246:2015. Metodyka vyznachennia hidravlichnoho stanu hazoprovodiv systemy zboru ta transportuvannia hazu $\mathrm{z}$ rodovyshch PAT «Ukrhazvydobuvannia»: nakaz PAT «Ukrhazvydobuvannia» No. 347. Kyiv, 2015. 39 p.

12. Pal'chikov V. P. Beskontaktnyy sposob indikatsii urovnya zhidkikh otlozheniy $\mathrm{v}$ gazoprovodnykh sistemakh // Peredovoy proizvodstvennyy i nauchno-tekhnicheskiy opyt, rekomenduemyy dlya vnedreniya $\mathrm{v}$ gazovoy promyshlennosti. 1989. Issue 2. P. $48-52$.

13. Farag A. M. Crude Oil Pipelines Inspection // Technology of Oil and Gas Forum and Exhibition. 2004.

14. Horin P. V., Tymkiv D. F., Holubenko V. P. Systematyzatsiia metodiv ochystky hazozbirnykh merezh dlia transportuvannia hazu zrilykh rodovyshch // Komunalne hospodarstvo mist. Seriia: Tekhnichni nauky ta arkhitektura. 2017. Issue 134. P. 52-57.

15. Farag A. M. Heavy Hydrocarbon Testing Methodology // The Micro CAD International Scientific Conference Hungary. Miskolc, 2004.

16. Farag A. M. Influence of Paraffin Flocculation in Crude Oil Tran sported Pipelines with Economic View of Pigging Process // 1st International Conference and Exhibition in Oil Field Chemicals. Tripoli, 2003.

17. Farag A. M. Wax Precipitation in Crude Oil Tran sporting Pipelines // The Micro CAD International Scientific Conference Hungary. Miskolc, 2004. 
18. Al-Yaari M. Paraffin Wax Deposition: Mitigation and Removal Techniques. SPE Saudi Arabia Section Young Professionals Technical Symposium. 2011. doi: http://doi.org/10.2118/155412-ms

19. Gupta A., Sircar A. Introduction to Pigging \& a Case Study on Pigging of an Onshore Crude Oil Trunkline. 2016. URL https://www.researchgate.net/publication/307583466_Introduction to Pigging a Case Study on Pigging of an Onshore Crude_oil_Trunkline Last accessed: 16.03 .2018

20. Skorobagach M. A. Problemy ekspluatatsii sistemy sbora gaza na mestorozhdenii Medvezh'e // Tekhnologii nefti i gaza. 2011. Issue 6. P. $42-47$

21. Bratakh M. I., Skrylnyk K. Yu., Burova M. Ya. Syntez zadachi transportuvannia bahatofazovykh seredovyshch truboprovidnoiu systemoiu // Intehrovani tekhnolohii promyslovosti. Intehrovani tekhnolohii ta enerhozberezhennia. 2013. Issue 4. P. 38-45.

22. Bratakh M., Romanova V. 2 - Phase and multiphase flows handling in gathering system. St. Andrews, 2017. P. 131-136.

23. Lemmon E. W., Huber M. L., McLinden M. O. NIST Standard Reference Database 23 Reference Fluid Thermodynamic and Transport Properties-REFPROP, Version 9.1. Standard Reference Data Program. Gaithersburg, 2013. URL: https://www.nist.gov/ publications/nist-standard-reference-database-23-reference-fluidthermodynamic-and-transport

24. Hughmark G. A. Holdup in Gas Liquid Flow // Chemical Engineering Progress. 1962. Issue 58. P. 62-65.
25. Panic D. Challenging Conventional Erosional Velocity Limitations for High Rate Gas Wells // CEED Seminar Proceedings. Chevron Australia Pty Ltd, 2009

26. American Petroleum Institute. Recommended Practice for Design and Installation of Offshore Production Platform Piping Systems. API RP 14E, Washington DC

Gorin Petro, Postgraduate Student, Department of Construction of Oil and Gas Pipelines and Gas Storage Tanks, Ivano-Frankivsk National Technical University of Oil and Gas, Ukraine, ORCID http://orcid.org/0000-0001-6312-5255,e-mail:petrogorin@gmail.com

Tymkiv Dmytro, Doctor of Technical Sciences, Professor, Head of the Department of Software, Ivano-Frankivsk National Technical University of Oil and Gas, Ukraine, ORCID: http://orcid.org/00000001-6054-143X, e-mail: informatik@nung.edu.ua

Bratakh Mikhailo, PhD, Division for the Collection, Preparation and Transport of Hydrocarbons of the Department of Ground Infrastructure, JSC UkrGasVydobuvannya, Kyiv, Ukraine, ORCID: http:// orcid.org/0000-0002-5464-7921,e-mail: mikhailo_bratakh@ukr.net

Filipchuk Oleksandr, Division for the Collection, Preparation and Transport of Hydrocarbons of the Department of Ground Infrastructure, JSC UkrGasVydobuvannya, Kyiv, Ukraine, ORCID: http://orcid.org/ 0000-0003-4255-1663,e-mail:oleksandr.filipchuk@outlook.com

\section{Lysyy A.,} Kotenko V., Yakovtsev $\mathbf{S}$.

\section{RATIONALIZATION OF PORT INFRASTRUCTURE MANAGEMENT DURING ICE NAVIGATION}

Об’єктом дослідження є управління морською портовою інфраструктурою в період льодової навігації. Одним з найбільш проблемних питань є раціоналізація і ефективність льодової проводки. На основі статистичних даних було відзначено значне зниження вантажообігу в портах Азовського моря (Маріуполь i Бердянськ (Україна)) протягом усього льодового періоду. Проведено дослідження необхідності використання аналізу і прогнозування сезонних процесів в управлінні виробничою діяльністю морських портів, за допомогою статистичних даних, для визначення динаміки вантажообігу морських портів в період льодової обстановки. На основі статистичного аналізу даних було сформульовано поняття сезонності льодоутворення в Азовському морі.

В прочесі дослідження дано визначення поняття фактора сезонності як категоріі, що виражається у вигляді коливальних прощесів. А також розроблено підхід до формування інформаційної бази, що враховує різні форми виробничої діяльності порту в умовах льодової обстановки, що задовольняє вимогам безперервного планування і регулювання роботи порту. Запропонований і розроблений словесний алгоритм прогнозу стану льодового покриву для формування караванів з метою статистичного прогнозування, включаючи всі стадї обробки динамічних рядів. В результаті було доведено суттєве зменшення вантажообігу портів в період льодової обстановки і запропоновані способи підвищення пропускної здатності водних шляхів в льодовий період. На думку авторів, за допомогою фактора сезонності і прогнозування льодоутворення, на основі словесного алгоритму, можна досягти зменшення витрат на використання криголама під час льодової навігації. Передбачається, що зниження виходів криголама в рейс може бути знижено з $10-15$ до 4-5. Це, в свою чергу, значно знизить витрати портів на утримання криголама і підвищить продуктивність портів під час льодової навігащії.

Ключові слова: управління морською портовою інфраструктурою, збільшення вантажообігу, морський порт, льодова навігащія.

\section{Introduction}

The management, organization and planning of yearround sea transportation largely depends on the influence of external factors, in particular on the conditions of the winter period of navigation. Rational management of the port infrastructure contributes to increasing the turnover of goods regardless of seasonal fluctuations. Under the port infrastructure refers to the set of available means of communication, transport terminals and vehicles that 